Of Bondage 



\section{Of Bondage}

\section{Debt, Property, and Personhood in Early Modern England}

Amanda Bailey

\section{$\overline{\text { PENN }}$}

UNIVERSITY OF PENNSYLVANIA PRESS 
Copyright (C) 2013 University of Pennsylvania Press

All rights reserved. Except for brief quotations used for purposes of review or scholarly citation, none of this book may be reproduced in any form by any means without written permission from the publisher.

\author{
Published by \\ University of Pennsylvania Press \\ Philadelphia, Pennsylvania 19104-4112 \\ www.upenn.edu/pennpress
}

Printed in the United States of America on acid-free paper $\begin{array}{llllllllll}10 & 9 & 8 & 7 & 6 & 5 & 4 & 3 & 2 & 1\end{array}$

Library of Congress Cataloging-in-Publication Data

Bailey, Amanda

Of bondage : debt, property, and personhood in early modern England / Amanda Bailey. — 1st ed.

p. $\mathrm{cm}$.

Includes bibliographical references and index.

ISBN 978-0-8122-4516-5 (hardcover : alk. paper)

1. Debt in literature. 2. Economics and literature-

Great Britain-History. 3. Debt-Great Britain-History. 4. Property-Great Britain-History. 5. English dramaEarly modern and Elizabethan, 1500-1600-History and criticism. I. Title.

PR3021.B35 2013

820.9 '3553-dc23 
For my family

The debt immense of endless gratitude . . still paying, still to owe.

Milton, Paradise Lost 
